\title{
Pronunciation in the Study of French: Attitudes of Teacher-Trainees in Colleges of Education in Ghana
}

\author{
Fiadzawoo Jonas Kwabla \\ University for Development Studies, Tamale, Department of Development \\ Education Studies \\ Yegblemenawo Stella Afi Makafui \\ Kwame Nkrumah University of Science and Technology, Department of \\ Modern Languages \\ Quansah Joseph Yaw Dwamena \\ University for Development Studies, Tamale, Department of Educational \\ Foundations
}

doi: 10.19044/esj.2017.v13n1p225 URL:http://dx.doi.org/10.19044/esj.2017.v13n1p225

\begin{abstract}
This study aims at finding out the attitudes of teacher trainees in selected colleges of education in Ghana towards the learning of French language pronunciation. To achieve this aim, Pronunciation Attitude Inventory (PAI) was used to collect field data from 229 French teacher trainees purposively selected from the five colleges of education responsible for training French teachers in Ghana. The participants were asked to respond to PAI comprising 13 statements on the five-point Likert scale. This was intended to elicit their views on the learning of pronunciation which has been introduced into their curriculum. The results which were analysed by the use of SPSS indicated that the teacher trainees have good attitudes towards the learning of pronunciation in the French language. It is believed that the trainees would in turn teach pronunciation after their graduation as French teachers. The article concludes with a suggestion to language teachers as well as curriculum planners to include components of pronunciation in language courses and help students to acquire correct pronunciation of words since this enhances mutual intelligibility in terms of communication.
\end{abstract}

Keywords: French language; pronunciation; attitude; colleges of education; teacher trainees 


\section{Introduction}

Researchers and practitioners, in recent years, have realised that pronunciation seems to be the orphan of second language teaching and learning due to its neglect both in classroom and research. It tends to be abandoned in the second language (L2) classroom, and teachers are somewhat intimidated by the idea of teaching pronunciation (Derwing \& Munro, 2005; Burgess \& Spencer, 2000). Asher and Garcia (1969) observe that pronunciation is less studied than other aspect of language due to its nature in terms of research. According to them, it is more difficult to conduct research into pronunciation than other aspects of language since many different variables interfere with its process such as gender, motivation, field dependence/independence, etc.

The neglect of teaching pronunciation in the classroom invariably affects most language learners. Ghana is not insulated from the difficulties with regards to good pronunciation as in the case of the study of the French language. The point of view of scholars such as Lado (1957); Corder (1992); Demirez (2010) and Liu (2011) depict that students in multilingual context such Ghana, could face challenges with the acquisition of correct pronunciations of French words. The major principle that underpins this phenomenon has been explained by Lado (1957) in his contrastive analysis hypothesis, as he indicates as follows:

"... those structures that are similar will be easy to learn because they will be transferred and may function satisfactorily in the foreign language. Those structures that are different will be difficult because when transferred they will not function satisfactorily in the foreign language and will, therefore, have to change" (Lado, 1957: 59).

Apart from the difficulty arising as a result of inexistence of some particular sounds in the L1 or L2 as pointed out by some researchers, the age of learners also plays a vital role in the acquisition of good pronunciation in the target language. Piske, MacKay \& Flege (2001) emphasise that age is a vital predictor in acquiring a foreign language accent. The age factor is further underscored by the Critical Period Hypothesis (CPH) (Lenneberg, 1967) which stipulates that learners have the disadvantages of starting to learn a language at late ages especially after puberty. This age factor also supports Long's (1990: 266) assertion that age 11 to 12 marks the end of the most favourable period for learners to acquire and speak fluently a new language; "a native-like accent is impossible unless one is first exposed quite early, probably before 6 in many individuals and about 12 in the remainder. Very high standards can be attained starting later, of course, but not; it seems nativelike standards". It can, therefore, be reiterated that if many of the French teaching departments in Ghanaian colleges of education and universities do 
not integrate learning of correct pronunciation in their courses, a great number of the French teacher trainees may not be confident enough with their own pronunciation levels and therefore, may either prefer not to teach pronunciation or unable to integrate it properly into their teaching. This, eventually, may affect learners of French, so far as the importance of good pronunciation in the target language is concerned.

Quite recently, a course that embraces techniques of transcribing French oral texts phonetically, (Phonetic Transcription), has been introduced in the colleges of education with the objective of improving pronunciation among French teacher trainees. Thus, as stated in the Draft French SyllabusInstitute of Education, U.C.C. (2014: 358), the aim is "To reinforce competence in correct pronunciation"; therefore, "students will be equipped with the requisite techniques of transcribing oral texts phonetically". The main objective is "to develop students' communicative competence in the four language learning skills" (p.358). This effort by the Institute, to a large extent, supports the old famous declaration of Jesperson who took language teachers to task for being afraid of the phonetic alphabets and exhorted as follows: "the use of phonetics and phonetic transcriptions in the teaching of modern language must be considered as one of the most important advances in modern pedagogy, because it ensures both considerable facilitation and exceedingly large gain in exactness". He further cautioned that: ".....these means must be employed immediately from the very beginning". He added that "Just as easy as it is to get a good pronunciation in this way, just as difficult it is to root out habits which may become inveterate during a very short period of instruction according to wrong or antiquated method" (Jesperson, 1904: 170-176; also cited in Derwing, 2010).

Reinforcing the correct pronunciation of the French language at the very beginning of the training of French teacher trainers should be seen as a good step that would go a long way to ensure good communication skills not only among the trainees but also pupils that they would teach in future; needless to say that pronunciation plays a vital role in communication, and the absence of it can bring about intelligibility problems. Intelligibility here means the degree to which a given utterance is understood by a listener (Derwing and Munro, 2005). It goes a long way to emphasize that, teachers with wrongful pronunciation or mispronunciation can be the fundamental reason for miscommunication among learners. It is, therefore, not an exaggeration for scholars to state that the utmost aim of learning a language is to enhance meaningful communication in social interaction (Hymes, 1972; Canale and Swain, 1980; Halliday, 1993). But what is the attitude of the teacher trainees towards this course that has been introduced to them? This concern is what this study intends to address. The following are questions that guide the study: 
1. What are the views of French teacher trainees about the need to study French pronunciation?

2. What is the attitude of French teacher trainees towards the learning of the pronunciation in the French language?

The word "attitude" is concerned with one's mind-set towards a topic or a tendency to act in a particular way due to an individual's experience. It is about one's "likes and dislikes" (Bem, 1970 cited in Schwarz \& Bohner, 2001). They are a complex combination of things we tend to call personality, beliefs, values, behaviors, and motivations. An attitude includes three components: an affect (a feeling), cognition (a thought or belief), and behavior (an action) (Schwarz \& Bohner, 2001). The study aims at finding the attitudes of the French teacher trainees towards the learning of correct pronunciation in French and it is presented as follows: the introduction is followed by the Literature review, Research questions, Purpose of the study, Methodology and finally, the Findings and Conclusion.

\section{Review of literature}

In the Foreign Language learning situation, learners usually find the target language pronunciation difficult because the new sounds do not always correspond to the ones in their L1. This has been difficult to handle by many teachers. So some schools of thought maintain that pronunciation needs to be presented explicitly (Derwing, 2010). This implies that pronunciation needs to be taught in class to help learners gain confidence in oral communication. In his study, Nakazawa (2012) states that, especially at the university level, students feel anxious and are afraid of making mistakes while pronouncing certain words in the target language, and they mostly confess that they get embarrassed when speaking. This phenomenon is equally confirmed by a study by Fiadzawoo (2015) in which out of 240 participants, sixty percent reported that they felt anxious about making mistakes in pronouncing French words especially among their colleagues. This issue is quite worrisome because one of the key factors in foreign language teaching is creating a "stress-free environment" and "lowering learners" anxiety as much as possible (Krashen, 2009: 32). Krashen's (2009) filter hypothesis explains why it is possible for an acquirer to obtain a great deal of comprehensible input, and yet stop short of good performance in terms of language acquisition and its usage. According to Krashen, this is as a result of the affective filter as illustrated below:

Input

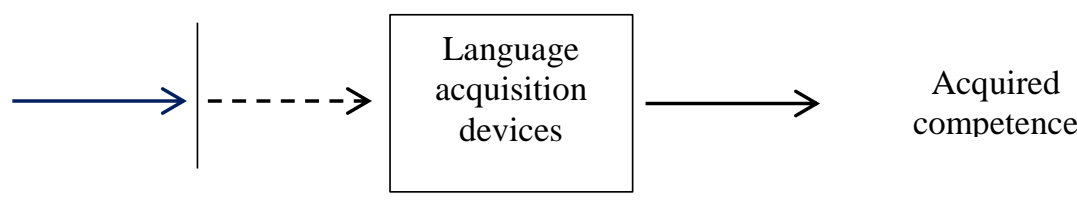

Operation of the "affective filter (Krashen, 2009:32) 
Krashen (2009), further, expounds that if the learner is too stressed, he or she cannot learn the new language as he or she cannot receive 'the comprehensible input' because of the anxiety, which is characterized as "affective filter". Based on this hypothesis, it is believed that in foreign language learning atmosphere, the affective filter plays an important role for producing correct pronunciation; a language learner may not progress successfully in skills of pronunciation because of fear of making mistakes in front of others.

Studies show that over the years, attention has not been adequately paid to correct pronunciation in language learning classrooms (Derwing \& Munro, 2005). Deng et al., (2009) lament that pronunciation is not an aspect of Second Language Acquisition that takes an academic attention and hence quite often suffers neglect in language teaching. In the field of research, there are few studies that attempted to find out the attitudes of teachers and learners towards the teaching/learning of pronunciation. These studies include Burgess and Spencer (2000); Derwing (2010); Foote, Holtby \& Derwing (2010) and Elliott (1995).

Burgess and Spencer (2000) conducted a study about the attitudes of language instructors and learners in the UK towards teaching and learning of pronunciation. The results showed that instructors found pronunciation difficult to teach and stated that learners especially had problems about the sounds that were not in existence in their L1. Also, Derwing (2010) has established that 53\% migrant students to Canada thought that Canadians would respect them more if they were good at pronunciation. Thus, the results prove that articulating the correct pronunciation in the target language may show the social status of the people or their educational background. People do not want to be seen different from the rest of their group so they would like to pronounce in a native-like way as much as they can. Another study by Foote, Tracey \& Derwing (2010) reveals that $75 \%$ of the Canadian instructors wished they could be trained, and so many language teachers avoid teaching pronunciation because they lack the confidence in their own ability to succeed it.

Other factors such as motivation, age of the learners as well as differences in the target and source language(s) of the learners also play vital roles in the teaching/learning of pronunciation. Motivation is one of the key elements of learning a target language as reemphasised by (Dörnyei, 1998). He underscores the importance of motivating the learner when he reiterates that "Without sufficient motivation, even individuals with the most remarkable abilities cannot accomplish long term goals" (Dörnyei, 1998:117). This assertion implies that it becomes invariably difficult to teach if the learner is not motivated or if the learners do not want to learn. From the point of view 
of Elliott (1995) which was also reemphasized by Suter (1976), learners who are concerned with their pronunciation had better pronunciation skills. Moreover, it is believed that learners with good pronunciation skills possess good communication skills as well. Sociolinguists and anthropological linguists like Hymes (1972) and his supporters Canale and Swain (1980) and Firthian linguists like Halliday (1993) view foreign language learning, first and foremost, as a system for meaningful communication in social interactions. Therefore, foreign language learners need to be encouraged and motivated to pay utmost attention to correct pronunciation and try to improve their overall communication skills. Gage and Berliner (1984) liken motivation to the engine (intensity) and steering wheel (direction) of a car. According to Brown (2000), motivation has two opposing camps: one of these stresses the importance of rewards and reinforcement, and the other states the cognitive process in a deeper sense. Gass and Selinker (2008) postulate further that individuals who are motivated will learn another language faster and to a greater degree.

The age of the learner is another essential issue that has a great influence on the correct pronunciation. According to Granena (2012), the age of the learner is an important predictor of acquiring foreign language pronunciation skills. Nunan (1998) also expounds that in every human life, there is a period during which language can be acquired more easily and after that period it becomes much more difficult. The age factor view was originally suggested by Lenneberg (1967) in his Critical Period Hypothesis which was later supported by Long (1990). Therefore, in the process of teaching/learning a new language pronunciation, the age of the learner should also be taken into consideration.

Moreover, the relationship between the target language and learners' source language(s) is also a key factor in acquiring good pronunciation skills. In Ghana, there is evidence that difference in structural elements in the target language-French and L2 (English Language) have much effect on students' performance especially in the target language (Amuzu, 2001 \& Fiadzawoo, 2012). Yiboe (2001) also conducted a study to find out the effect of the mother tongue or L1 (Ewe) on the target language (French) which confirms that some French phonemes are wrongly pronounced by students who had Ewe as their L1. According to him, this wrongful pronunciation is due to non-existence of such French phonemes in the students' L1. These findings prove, to some extent, that negative language transfers either from mother tongue (L1) or English language (L2) can negatively affect good communication in the French language, especially, when the learner communicates with native speakers of French or the Francophone Africans whose countries actually share frontiers with Ghana. Hismanoglu (2009) equally observes that nonnative teachers of the English language in Turkey do not have phonological 
competence to teach pronunciation clearly. His observation buttresses the point that the incompetence of the language teacher, in any skills of the language he or she teaches, can result in lack of particular language skills for his/her learners. This is because it is easy for the incompetent teacher to transfer his/her short-comings to the learners during classroom interactions. Byram, Gribkova and Starkey (2002) assert that individuals learn language as they interact with speakers (also teachers) of the language.

Concerning French language teaching in Ghana, currently out of the 39 Colleges of Education (including one private) in the country, only five are responsible for training French teachers for basic schools (Institute of Education, 2015). However, two public universities namely; University of Cape Coast, Cape Coast and University of Education, Winneba also train French teachers who teach in both basic and secondary schools. Not until 2001, the then Mount Mary College was the only institution responsible for training French teachers in Ghana for basic schools. Two additional colleges namely; Wesley College of Education, Kumasi and Bagabaga College of Education, Tamale, began offering French in the year 2001 (Yiboe, 2007). However, in 2013, two more colleges were upgraded to start training French teachers: Evangelical Presbyterian (EP) College of Education, Amedzofe College of Education and Gbewa College of Education. These Colleges were added to augment the intake of the French teacher trainees in the country to promote the teaching and learning of the language. It is on record that another college of education (Wenchi College of Education, Wenchi) is currently being piloted for training French teachers. However, this study did not include it because products have not yet written any examination conducted by the Institute of Education, UCC, Cape Coast as at the time this study was conducted. Despite this marginal increment and the upgrading of the training colleges from 3-year Post-Secondary Certificate awarding institutions to a 3year Diploma awarding Colleges of Education, Yiboe (2007) estimates that the turnout of French teachers from the Colleges of Education in recent times are of a low standard.

With regards to the linguistic background of the French teacher trainees of the colleges of education in Ghana, the majority is multilingual. This is on the basis that most educated Ghanaians are multilinguals (Amuzu, 2001; Edu-Buandoh, 2008; Fiadzawoo, 2012; Kuupole, 2012; De-Souza, 2013). Thus, apart from the English Language (L2), which is the official language and medium of instruction in Ghanaian schools beginning from Primary Four, these students speak scores of indigenous Ghanaian languages. It is worth of note that Ghana has over 67 spoken languages (Kropp, 1988 also cited by Yiboe, 2010). The major languages of Ghana consist of $K w a$ of the West (Akan, Ga-Adangbe, Guan and Ewe) and Gur of the North of the Volta River (Mole-Dagbani, Gurma and Grusi). Akan is the most widely spoken 
Ghanaian language; about $50 \%$ of Ghanaians speak Akan in addition to their own native languages (Tsivanyo, 2010). The French language, on the other hand, has a status just like Spanish, Chinese, Swahili and Russian which are studied as foreign languages. But unlike the other foreign languages which are studied mostly only in the tertiary and private institutions, French is pursued not only at the tertiary but also at the basic and secondary school levels of education in Ghana. This phenomenon is due to the geographical, political and socio-economic exigencies of the French language (Amuzu, 2001 \& Kuupole, 2012). It is these demands of the language that necessitate the training of French teachers at different levels both at the colleges of education and the two public universities.

It is believed that since language learning is quite favourable at the earlier ages of life (Lenneberg, 1967; Long, 1990; Nunan, 1998; Granena, 2012), it is quite essential to get the teacher trainees who are going to teach at the basic level on board by sensitizing them about the essence of teaching and learning of pronunciation so that after the completion of their training programme, they will in turn impart their rich experience to the pupils in the basic schools.

\section{Methodology}

\section{Research Design}

The study is based on descriptive survey. The researchers adopt descriptive survey approach, which is primarily concerned with looking at the phenomenon under consideration in order to determine the existing state of affairs. According to Best and Kahn (1998) the descriptive survey study describes and interprets what exist. It is concerned with conditions or relationships that exist, opinions that are held, processes that are going on, effects that are evident, or trends that are developing. Fraenkel and Wallen (2000) believe that to obtain answers from a large group of people to a set of carefully designed and administered questionnaire is the heart of survey research. Cohen and Manion (1989) on their part, reiterate that data in descriptive survey are usually collected through the use of self-completion or postal questionnaire interviews (structured or semi-structured), standardized tests of attainment or performance, attitude scales, and observations.

The survey administered was based on Pronunciation Attitude Inventory (PAI) adapted from Elliott, (1995). This survey involves 13 statements about pronunciation, and it is constructed in the form of five-point Likert scale which ranges from "always or almost true of me" to "never or almost never true of me". However, some parts of the survey instrument have been evaluated and modified in accordance with the purpose of the research. Before arriving at the final version, which was eventually administered, two experts in the field were asked to review it. In addition, prior to the collection 
of the data, the researchers had a discussion with the participants and explain to them, the purpose and the importance of the study. The participants were also assured of the confidentiality of their information given and the freedom they had to choose to be part of the study or not. The discussion was a measure to fulfill the ethical dimension needed in the research. Finally, the questionnaire was administered to the participants without giving them any time limitation in order to create a relaxed atmosphere while they respond to the questions.

\section{Participants}

The participants were selected from the five Colleges of Education responsible for training French teachers, namely: Bagabaga College of Education (Tamale), Wesley College of Education (Kumasi), Mount Mary College of Education (Somanya), Evangelical Presbyterian College of Education (Amedzofe) and Gbewaa College of Education (Pusiga). The participants were in the second year and were purposively selected for the study. Amoani (2005), Creswell (2005) and Sarantakos (1997) contend that in purposeful sampling, respondents are handpicked to be included in the sample and to develop samples that are satisfactory in relation to the researchers needs. The selection of the second year teacher trainees (229 in number) was purposive because they were pioneers to start so far as the course in the Phonetic Transcription is concerned since it has just been recently introduced into the Diploma in French Education Programme.

The distribution of the participants according to the respective Colleges of Education is shown below in Table 1.

Table 1: Distribution of the Participants by Colleges

\begin{tabular}{lcc}
\hline $\begin{array}{l}\text { Name of } \\
\text { Colleges }\end{array}$ & $\begin{array}{c}\text { Participa } \\
\text { nts }\end{array}$ & $\begin{array}{c}\text { Percentage } \\
(\%)\end{array}$ \\
\hline $\begin{array}{c}\text { Gbewaa College of } \\
\text { Education. }\end{array}$ & 29 & 12.7 \\
Bagabaga College of & & 12.7 \\
$\quad$ Education. & 29 & 13.1 \\
$\begin{array}{l}\text { E.P. College of Education. } \\
\text { Wesley College of }\end{array}$ & 30 & 26.6 \\
$\quad$ Education. & 61 & 34.9 \\
Mount. Mary College of & & 100 \\
$\quad$ Education. & 80 & \\
\hline Total & 229 &
\end{tabular}

As indicated in table 1, Mount Mary College of Education which is the oldest in Ghana in terms of training French teachers leads in the admission of teacher trainees. Thus, out of the total of 229 participants, $80(34.9 \%)$ are from the Mount Mary College of Education and this is followed by Wesley College of Education, Kumasi with the record of 61 teacher trainees representing 
$26.6 \%$ of the total participants. E. P. College of Education had 30 participants representing (13.1\%) while Gbewaa and Bagabaga Colleges of Education both had 29 participants representing $12.7 \%$ respectively. On record, the three Colleges, namely: Gbewaa College of Education, Bagabaga College of Education and E. P. College of Education, had 30 students each in the second year, while Wesley College of Education had 66 students (Assessment Unit, Institute of Education, UCC (2014). However, at the time of collecting this data, only these participants as shown above in the table were available for the study. The result is an indication that more education needs to be done to advertise the newly established Colleges to enhance their acceptability by prospective students as their admission of students is still very low. The sex distribution of the participants is shown below in Table 2 .

Table 2: Distribution of Participants by Sex

\begin{tabular}{ccc}
\hline SEX & Participants & Percentage $(\%)$ \\
\hline MALE & 89 & 39.2 \\
FEMALE & 138 & 60.8 \\
\hline TOTAL & 227 & 100 \\
\hline
\end{tabular}

Also the age distribution of the participants is shown below in Table 3

Table 3: Distribution of Participants by age

\begin{tabular}{cccc}
\hline AGE & Participants & & Percentage(\%) \\
\hline $16-20$ & 41 & 18.1 & \\
$21-25$ & 151 & 66.8 & \\
$26-30$ & 32 & 14.2 & \\
$31-35$ & 1 & 0.4 & \\
$36-40$ & 1 & 0.4 & \\
\hline TOTAL & 226 & 100 & \\
\hline
\end{tabular}

As shown in the Table 3 above, the ages of the participants ranges from 16 to 39 with those between the ages of 21 to 24 recording the highest percentage of $66.8 \%$ of the total participants. The result shows that most of the participants have passed the most favourable age for learning to acquire and speak a new fluently. However, this circumstance might not have much effect on the participants since most of them might have started learning the French language either from the Junior High School or the Senior High School.

\section{Data analysis}

The results were analyzed through SPSS 18 programme with the use of descriptive statistics and frequencies. Each item has also been analyzed taking into consideration the following statistical relations: mean, standard 
deviation, minimum and maximum values. This analysis helped to determine attitudes of the participants towards the phenomenon under investigation.

\section{Results and discussion}

The first analysis was based on Table 4 as shown below. The figures in the table are based on the statistical results of the thirteen items in general. As shown in Table 4, there is no missing value, meaning the participants responded to all statements. Concerning the statements, there is a maximum value of five which states "always or almost always true of me" and the minimum value is one which also states "never or almost never true of me. Also, we also have "usually true of me" and "usually not true about me" which carry the values of four and two respectively. The middle way however, is "somewhat true of me" which carries the value of 3.

In the table, the items 4 and 11 scored high mean values of 4.51 and 4.46 respectively. The statements of the two items suggest positive attitude of the respondent towards the learning of pronunciation. The item 4 states " $I$ believe I can improve my pronunciation skills in French and the item 11 also states: I am concerned with my progress in pronunciation of French. With regards to the responses given, the implication is that the majority of the participants think positively about these two statements. This means, only few participants that think absolutely in a negative direction about these two statements. These responses further imply that students are careful about their pronunciation skills and determined to improve it.

There is also another implication which can be deduced from the mean value of Item (10) and item 3. As indicated in the table, item 10 with the statement "I want to improve my accent when speaking French" has the high mean value of 4.34 while item 3 has the lowest mean value of 1.86 with the statement "I will never be able to speak French with good accent. These results depict the positive attitudes of the participants towards learning pronunciation in French. It is an indication that the participants are not complacent in terms of learning to improve their pronunciation in the target language. In other words, the participants were motivated enough to improve their pronunciation skills in the French language; an attribute which is a positive. The item 3 further explains the determination of the respondents to learn to speak French accurately. With the lowest mean value of 1.86 , the implication is that the participants believe that they can learn to speak French with good accent. This assertion supports the fact that students really embraced the Phonetic Transcription introduced in their curriculum and have attached great importance to the learning of it with a belief that by the end, they would be able to speak French with good accent. Undoubtedly, it is reflected in the response given to the Item 2; Acquiring proper pronunciation in French is 
important to me, with the high mean value of 4.52. The table can be found below:

Table 4: Descriptive Statistics of the items

\begin{tabular}{ccccc}
\hline ITEM & MEAN & ST. Dev. & Min. & Max. \\
\hline 1 & 4.26 & 1.10175 & 1 & 5 \\
2 & 4.52 & 0.78125 & 1 & 5 \\
3 & 1.86 & 1.31997 & 1 & 5 \\
4 & 4.51 & 0.85767 & 1 & 5 \\
5 & 4.45 & 0.8183 & 1 & 5 \\
6 & 4.58 & 0.78935 & 1 & 5 \\
7 & 3.98 & 1.04086 & 1 & 5 \\
8 & 3.70 & 1.21599 & 1 & 5 \\
9 & 2.68 & 3.52709 & 1 & 5 \\
10 & 4.34 & 0.85694 & 1 & 5 \\
11 & 4.46 & 0.77475 & 1 & 5 \\
12 & 3.24 & 1.38613 & 1 & 5 \\
13 & 4.19 & 1.09767 & 1 & 5 \\
\hline
\end{tabular}

The responses given to the items in the questionnaire that intended to find out the attitudes of participants show that correct pronunciation plays an essential role in learners' motivation towards the French language. The following items in the questionnaire are intended to present the respondents view on the significance of learning the target language pronunciation: 1, $2,6,10$, and 12 . These statements also aimed at finding out to what extent the respondents were willing to improve their pronunciation in the French language. The results are shown below in the table 5 .

Table 5: Number and responses of participants to statements 1,2, 6, 10 and 12.

\begin{tabular}{|c|c|c|c|c|c|c|c|c|}
\hline $\begin{array}{l}\mathrm{IT} \\
\mathrm{E} \\
\mathrm{M}\end{array}$ & STATEMENTS & DS & 1 & 2 & 3 & 4 & 5 & $\begin{array}{c}\text { TO } \\
\text { TA } \\
\text { L }\end{array}$ \\
\hline \multirow[t]{2}{*}{1} & $\begin{array}{l}\text { I would like to sound as } \\
\text { native as possible when } \\
\text { speaking French }\end{array}$ & $\mathbf{F}$ & $\begin{array}{l}1 \\
2\end{array}$ & 8 & $\begin{array}{l}1 \\
9\end{array}$ & $\begin{array}{l}5 \\
8\end{array}$ & $\begin{array}{l}1 \\
2 \\
9\end{array}$ & 226 \\
\hline & & $\%$ & $\begin{array}{l}5 . \\
3\end{array}$ & $\begin{array}{l}3 . \\
5\end{array}$ & $\begin{array}{l}8 . \\
3\end{array}$ & $\begin{array}{l}2 \\
5 . \\
7\end{array}$ & $\begin{array}{l}5 \\
7 . \\
1\end{array}$ & 100 \\
\hline \multirow[t]{2}{*}{2} & $\begin{array}{l}\text { Acquiring proper pronunciation in French } \\
\text { is important to me }\end{array}$ & $\mathbf{F}$ & 3 & 5 & 8 & $\begin{array}{l}6 \\
7\end{array}$ & $\begin{array}{l}1 \\
4 \\
9 \\
\end{array}$ & 232 \\
\hline & & $\%$ & $\begin{array}{l}1 . \\
3\end{array}$ & $\begin{array}{l}2 . \\
2\end{array}$ & $\begin{array}{l}3 . \\
5\end{array}$ & $\begin{array}{l}2 \\
9 . \\
3\end{array}$ & $\begin{array}{l}6 \\
3 . \\
8\end{array}$ & 100 \\
\hline
\end{tabular}




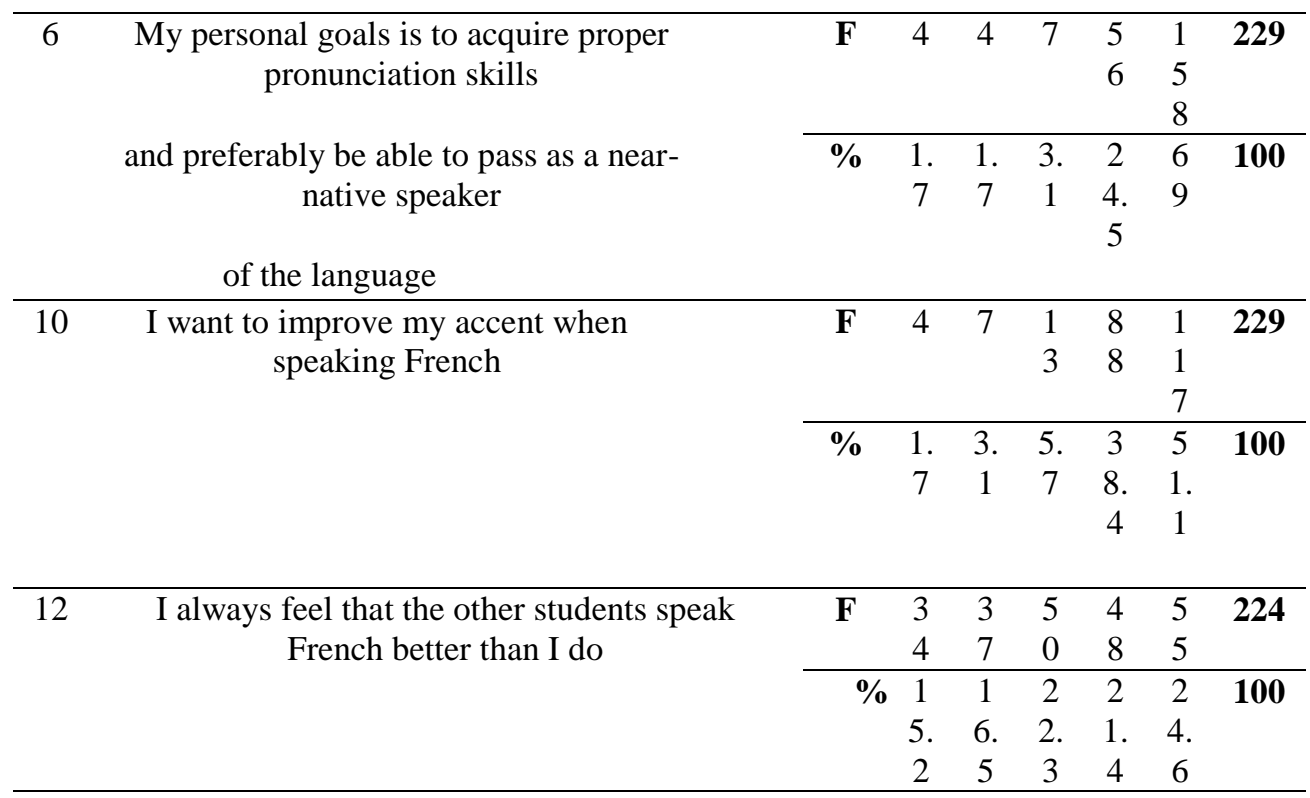

From the results shown above in table 5, the item 1 intended to find out from the participants the importance of correct pronunciation. As indicated on the table, $82.8 \%$ (57.1 and 25.7) of the participants would like to sound as native as possible while speaking French. This objective is collaborated by the results of the item 10 with the percentage of 89.5 (51.1\% and 38.4\%) which indicated that the participants have the desire to improve their accent when speaking French. Moreover, the results obtained from items 2 and 6 revealed that, to acquire proper pronunciation in French is very significant to participants and they intend to use French properly 'to pass a near-native speaker'. This assertion is shown with the percentage of $93.5(69 \%$ and $24.5 \%)$. This revelation from the participants is very heart-warming. However, as indicated by several studies, it is difficult to achieve such a goal ('to pass a near-native speaker') especially at a particular period in life due to certain factors including age, motivation and even the duration of the programme being pursued. Nonetheless, as identified by researchers such as Derwing (2010), the optimal use of technology, enhancement of listeners' skills, and strategies for increasing students' opportunities to interact with native speakers are measures identified as practical approaches that can be used to help students to achieve this goal.

The next table focuses on the responses of the participants to the statements 3, 4 and 5 . 
Table 6: The responses of participants to statements 3, 4 and 5

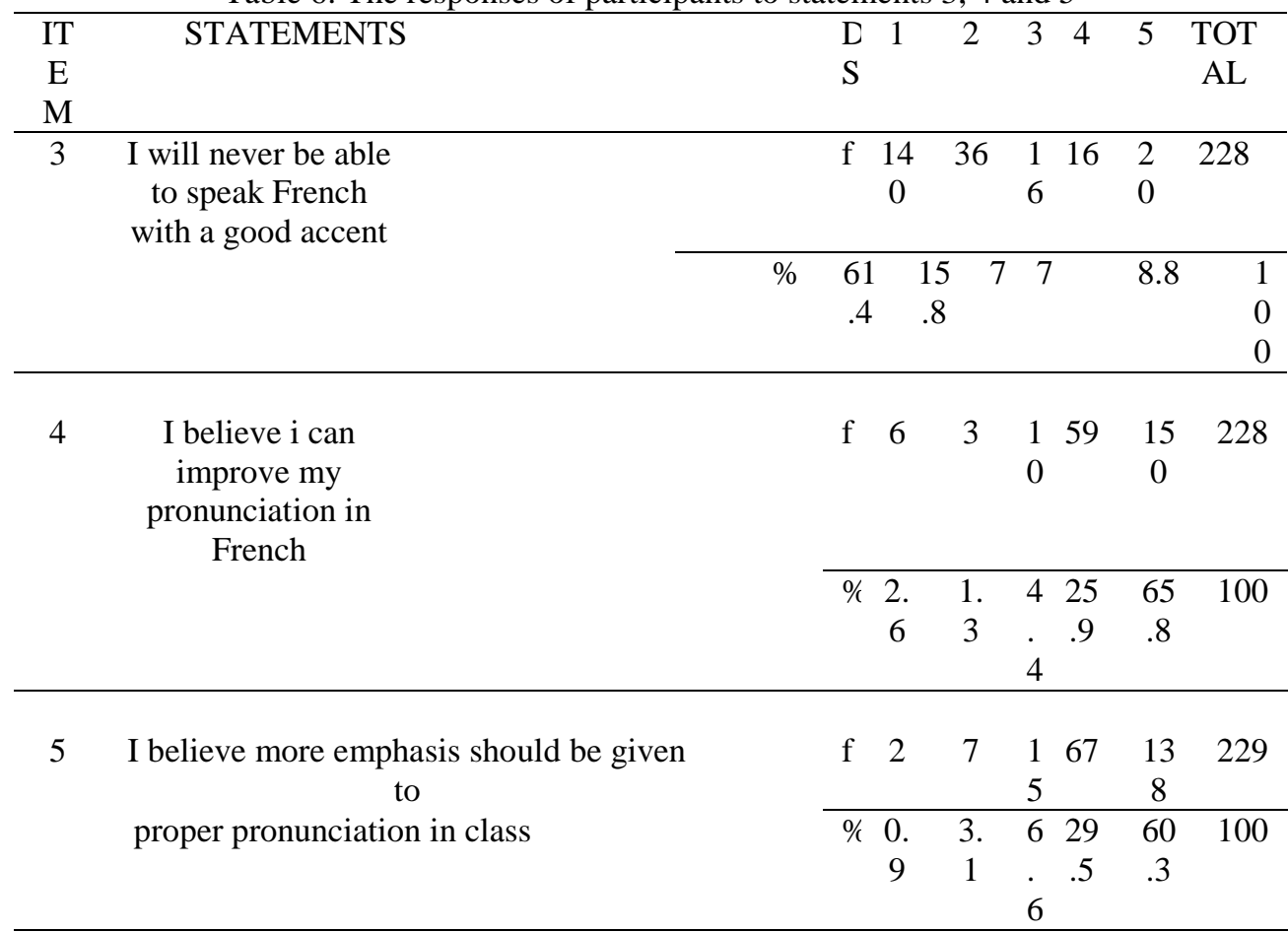

As shown above in table 6, Items 3 and 4 requested respondents to state their opinions about the achieving the correct pronunciation in French. Item 3 states, "I will never be able to speak French with a good accent ", one of the negative statements elicited from the questionnaire obtained the lowest mean score 1.86 which also means 87.2\% (61.4 and 15.8) disagree with the statement. In other words, this result implies that the participants do not agree with this statement and think that they can have a good accent. In addition, the item 4 reveals that the participants show positive attitude towards learning the target language pronunciation. This statement is confirmed by $91.7 \%(65.8$ and 25.9) of the participants. Finally, the result from item 5 indicates that 89. $8 \%$ (60.3 and 29.5) of the participants believe that more emphasis should be given to the learning of proper pronunciation in French class. It is therefore, justified to state that the participants believe that more emphasis on the teaching of good pronunciation of the French language in the classroom can enhance their acquisition of the language and further improves their communicative skills and competence.

Table 7 below examines the response of the participants to the statements $7,8,9,11$, and 1 
Table 7: The responses of Participants to statements 7, 8, 9, 11, and 13

\begin{tabular}{|c|c|c|c|c|c|c|c|c|c|}
\hline ITEM & STATEMENTS & & DS & 1 & 2 & 3 & 4 & 5 & TOTAL \\
\hline \multirow[t]{2}{*}{7} & I try to imitate French & $\mathbf{F}$ & 7 & 16 & 35 & 86 & 84 & \multicolumn{2}{|c|}{228} \\
\hline & & & $\%$ & 3.1 & 7 & 15.4 & 37.7 & 36.8 & 100 \\
\hline \multirow[t]{2}{*}{8} & Communicating is much more & $F$ & 18 & 20 & 39 & 79 & 66 & \multicolumn{2}{|r|}{222} \\
\hline & & & $\%$ & 8.1 & 9 & 17.6 & 35.6 & 29.7 & 100 \\
\hline \multirow[t]{2}{*}{9} & Good pronunciation skills in French & $\mathbf{F}$ & 86 & 42 & 31 & 41 & 26 & \multicolumn{2}{|r|}{226} \\
\hline & & & $\%$ & 37.9 & 18.5 & 13.7 & 18.1 & 11.5 & 100 \\
\hline \multirow[t]{2}{*}{11} & I am concemed with my & $\mathbf{F}$ & 2 & 5 & 13 & 75 & 134 & \multicolumn{2}{|r|}{229} \\
\hline & & & $\%$ & 0.9 & 2.2 & 5.7 & 32.8 & 58.5 & 100 \\
\hline \multirow[t]{2}{*}{13} & Sounding like a native & $\mathbf{F}$ & 10 & 14 & 17 & 68 & 119 & \multicolumn{2}{|r|}{228} \\
\hline & & & $\%$ & 4.4 & 6.1 & 7.5 & 29.8 & 52.2 & 100 \\
\hline
\end{tabular}

As indicated above in the table 7, item 7 carries the statement "I try to imitate French speakers as much as possible. By the statistical proportions, $74.5 \%$ (36.8 and 37.7) of the participants agreed with this statement; an indication that students would like to sound like the native speakers. This result depicts that most of the students have so much ambition or motivation in terms of speaking the French, hence their desire to imitate native speakers. In the Ghanaian context, French is learnt devoid of the contact with native speaker. It appears, therefore, difficult to sound like the native speakers; this quality can only be achieved if the students could get a programme put in place to stay with the native speakers for some number of years. With the statement 8, 65.3\% (29.7 and 35.6) indicated that "communication is much more important than sounding like a native speaker". This statement really buttresses the core value of learning any language which is to achieve communication. That is to emphasise that it is very important to learn the pronunciation of words in the target language, but the main aim of learning any language should be to communicate effectively in that language. Also, the result indicated that the participants place premium on the pronunciation and believe that it is as important as the most aspect of language such as vocabulary and grammar. As shown above in the table 7, $56.4 \%$ (37.9 and 18.5) out of the participants who responded to the statement reject the fact that "good pronunciation skills in French are not as important as learning vocabulary and grammar". It is also revealed that the participants are generally concerned about their progress in the learning of the pronunciation. This assertion is support by their overwhelming response to the fact that they are concerned with their own progress in the pronunciation of French as 
indicated by the responses to the item 11 . Ninety one percent $(91 \%)$ of the participants are much concerned about their progress in the learning of the pronunciation of the French language. In all, the majority of the students have the view that they can improve their pronunciation skills and are determine to do that. The view is based on the belief that pronunciation is as an aspect of language just as important as the grammar and vocabulary.

\section{Findings and Conclusion}

This study sought to find out the attitude of French teacher trainees towards the importance of pronunciation in the learning of French The results obtained demonstrate that the French teacher trainees investigated have a high expectation of learning the language; that is not only French lexis and structure but also French phonetics and phonology. To this effect, it can be said that the French teacher trainees have positive attitude towards learning the correct pronunciation in the target language. This also implies that they have really embraced the introduction of the Phonetic Transcription into their existing curriculum. It is believed that by teaching the teacher trainees the correct pronunciation of the French words through Phonetic Transcriptions, their phonetic awareness would be raised; they would know that pronunciation is not a skill that learners can acquire on their own, but special efforts need to be spent on teaching it in the classroom. It is essential that French language classes should give importance to correct pronunciation, stress and intonation as stipulated by the newly drafted French syllabus for the colleges of education.

The results of the study prove that the French teacher trainees are very motivated and hopeful about their pronunciation skills, and they also believe that they can improve their skills and achieve good foreign accent without necessarily imitating the native speakers.

The other significant finding of this study is that the participants, to a large extent, have a common belief that pronunciation plays a great role in establishing mutual intelligibility, which as suggested by Morley (1991), is an essential component of communication competence. The communicative competence forms the chore guiding principles of the Communicative Approach to language teaching. Larsen-Freeman (2000) believes that speaking is prior to other skills. The speaking skills should be integrated from the beginning and to achieve this aim, "students should work on discourse or suprasegmental features (above the sentence level)" (Larsen-Freeman, 2000: 126). Fluency and accuracy are seen as the complementary principles underlying communicative techniques. However, at times, fluency may take on more importance than accuracy in order to keep learners meaningfully engaged in language use (Brown, 2000). Teachers are, therefore, advised to use the target language fluently and appropriately by acting as advisors or 
facilitators. To add the suggestion of Otlowski, (1998), teachers and curriculum planners should ideally include components of pronunciation in language courses and help students to learn them. In this respect, what is expected from the tutors of French language in the Colleges of Education is to help their students acquire good pronunciation in the French language to foster their intelligibility of speech. Mutual intelligibility needs to be the modus operandi when considering what should be taught in the oral aspects of the language. Since research is inexhaustible, it will be heart-warming to discover in the near future, studies that find out whether the French teacher trainees have gain language competence both in pronunciation and communication in general as a result of the conscious learning of pronunciation through Phonetic Transcriptions.

\section{References:}

1. Amoani, F. K. (2005). Introduction to Research Methodology. An Overview. Winneba: University of Education, Winneba.

2. Amuzu, D.S.Y. (2001). 'L'impact de l'éwé et l'anglais sur l'enseignement/apprentissage du Français Langue Etrangère au Ghana". New Trends in Languages in contact in West Africa. Kuupole, D.D. (ed). Takoradi, St Francis Press: 1-19.

3. Asher, J. J., Garcia, R. (1969). "The optimal age to learn a foreign language". Modern Language Journal, 53, 334-341

4. Bem, D. J. (1970). Beliefs, attitudes, and human affairs. Belmont, CA: Brooks/Cole.

5. Best, J. W. and Ka, J. V. (1998). Research in Education. 8th Edn., Boston: Allyn and Bacon

6. Brown, A. (2001). Functional load and teaching of pronunciation. In Adam Brown (Ed.)Teaching English pronunciation.A book of readings. Londo: Routledge.

7. Brown, H. D. (1994). Principles of language learning and teaching. London: Practice Hall Regent.

8. Brown, H. D. (2006). Principles of language learning and teaching. ( $5^{\text {th }}$ ed.) London: Practice Hall Regent.

9. Burgess, J.K., Spencer, S. (2000). "Phonology and pronunciation in integrated language teaching and teacher education". System, 28,191215

10. Byram, M., Gribkov, B., \& Starkey, H. (2002). Developing the intercultural dimension in Language teaching. A practical introduction for teachers. Language Policy Division: Strasbourg.

11. Çakir, I., Baytar B. (2014). "Foreign language learners views on the importance of the target language pronunciation". Journal of language and linguistics studies. 10 (1), 99-10. 
12. Canale, M., \& Swain, M. (1980). "Theorical bases of communicative approaches to second language teaching and testing", Applied linguistics, 1 (1980), 1-46.

13. Cohen, L., \& Manion, L. (1989). Research methods in education. 3rd Ed., London: Routledge

14. Corder, S P. (1992). "A role for the mother tongue" Language transfer in language learning, L. Selinker \& S. M. Gass (Eds.), (Revised ed., pp 18-31). Amsterdam/ Philadelphia: John Benjamins.

15. Creswell, John W. 2005. Educational research: Planning, conducting, and evaluating quantitative and qualitative research. Upper Saddle River, New Jersey: Pearson

16. Demirezen, M. (2010). The causes of the schwa phoneme as a fossilized pronunciation problem for Turks. Procedia Social and Behavioural Science, 2, 1567-1571.

17. Deng, J., Holtby, A., Howden-Weaver, L., Nessim, L., Nicholas, B., Nickle, K., Sun, M. (2009). "English pronunciation research: The neglected orphan of second language acquisition studies". Prairie metropolis centre working paper series. WP05-09. Edmonton, AB.

18. Derwing, T. M. \& Munro, M. J. (2005). "Second language and pronunciation teaching: a research-based language approach". TESOL Quarterly, 39, 379-397.

19. Derwing, T. M. (2010). "Utopian goal for pronunciation teaching". Proceedings of the $1^{\text {st }}$ pronunciation in the second language learning and teaching conference, J. Levis \& K. LeVelle (Eds) Iowa State University, September,2009 (pp. 24-37). Ames, IA : Iowa State University.

20. De-Souza, A. Y. M. (2013). Stratégies de compréhension écrite sur l'internet. Quelles approches pédagogiques adopter pour développer l'autonomie en FLE dans les universités du Ghana. Unpublished PhD dissertation, University of Cape Coast, Ghana.

21. Dornyei, Z. (1998). "Motivation in second and foreign language learning”. Language teaching $31 . \quad 117-135$. Doi:10.1017/026144480001315X.

22. Dunn, A. K.,\& Stacey, P. C. (2000). An introduction to sensation, perception and attention. London: Sage Publication Ltd

23. Edu-Buandoh, D. F. (2008). "On subtractive multilingualism and cultural capital".Teaching and learning of language, culture and literature of West Africa. Kuupole, D. D. (ed) Takoradi : St Francis Press. 158-166.

24. Elliott, R. A. (1995). "Foreign language phonology: Field independence, attitude, and the success of formal instruction in 
Spanish pronunciation”. The Modern Language Journal, 79 (4), 530542.

25. Fiadzawoo, J. K. (2012). Influence de la syntaxe anglaise sur l'écrit des apprenants de FLE. Le cas de quelques écoles secondaires dans la métropole de Cape Coast au Ghana. Sarrebruck, Editions Universitaires Européennes.

26. Fiadzawoo, J. K. (2015). "Investigating speaking anxiety among adult Foreign Language (French) learners in the Faculty of Education, UDS, Tamale". Education Research Journal (International Research Journals). Vol. 5(2): 14-26. ISSN: 2026-6332 (http://www.resjournals.ARJ).

27. Foote, J. A., Holtby A. K., Derwing, T. M. (2011). "Survey of the teaching of pronunciation in adult ESL programs in Canada". TESL Canada Journal, 29 (1), 1-22.Fraenkel, Jack R. \& Wallen, Norman E. 2000. How to design and evaluate research in education. 4th Edn., New York: McGraw Hill Co.

28. Freeman, D.L. (2000). Techniques and practices in language teaching. Oxford: University Press.

29. Gage, N. L. \& Berliner, D. C. (1984). Educational psychology (3 ${ }^{\text {rd }}$ ed.). Boston: Houghton Mifflin.

30. Gass, S. M., \& Selinker, L. (2008). Second language acquisition: An introducatory course ( $3^{\text {rd }}$ ed). New York: Routledge.

31. Granena, G. (2012). Age difference and cognitive aptitudes in ultimate second language attainment. PhD. Dessertation, University of Maryland.

32. Granena, G., Long, M. H. (2011). Age of onset, length of residence, language aptitude, and ultimate L2 attainment in three linguistic domains. Ms: University of Maryland.

33. Halliday, A. (1993). Appropriate methodology and social context. Cambridge: Cambridge University Press.

34. Hayes, N. (1998). Foundations of psychology: An introductory text ( $2^{\text {nd }}$ Ed.). London: Thomas Nelson \& Son Ltd.

35. Hismanoglu, M. (2009). "Teaching word stress to Turkish EFL (English as a foreign language) learners through internet-based video lessons". US-China Education Review, 1, 26-40.

36. Hymes, Dell. (1972). "Models of interaction of language and social life". Directions in sociolinguistics: The Ethnography of Communication. J. Gumperz and D. Hymes (Eds). New York: Holt, Rinehart, Winston.

37. Institute of Education (Assessment Unit). (2014). University of Cape Coast 
38. Jesperson, O. (1904). How to teach a foreign language. London: George Allen\& Urwin Ltd.

39. Johnson, K., \& Johnson, H. (1999). Encyclopedic Dictionary of Applied Linguistics. Oxford: Blackwell.

40. Krashen, D. S. (2009). Principles and Practice in Second Language Acquisition (internet ed): New York: Pergamon Press Inc

41. Kropp, D. E. (1988). Languages of Ghana. London: Kegan Paul Inc.

42. Kuupole, D. D. (2012). From the savannah to the coastal lands in search of knowledge through the French Language. A herd boy's tale. An inaugural lecture delivered by Kuupole D.D.. Cape Coast, University Press.

43. Lado, R. (1957). Linguistic Across Cultures. Ann Arbor: The University of Michigan.

44. Larson-Freeman, D. (2000). Techniques and principles in language teaching. Oxford: Oxford University Press.

45. Lenneberg, E. H. (1967). Biological foundations of language. New York: Wiley.

46. Liu, Qian. (2011). "Factors influencing pronunciation accuracy. L1 negative transfer, task variables and individual aptitude". English Language Teaching, 4 (4) 115-120).

47. Long, M. H. (1990). Maturation constraints on language development. SSLA, 12: 251-285.

48. Morley, J. (1991). The pronunciation component in teaching English to speakers of other languages. TESOL Quarterly, 25 (3), 481-520. Doi: $10.2307 / 3586981$.

49. Nakazawa, K. (2012). The effectiveness of focused attention on pronunciation and intonation training in tertiary Japanese language education on learners' confidence. International Journal of Learning, 18 (4), 181-192. Retrieved from http://iteslj.org/Article/OtlowskiPronunciation.

50. Nunan, D. (1998). Second language teaching and learning. Boston: MA, Heinle ELT.

51. Otlowski, M. (1998). "Pronunciation. What are the expectations?" The Internet TESL. Journal, 4 (1). http://iteslj.org/Articles/OtlowskiPronunciation.html (retrieved on the 10th November, 2015).

52. Piske, T., MacKay, I. R. A. \& Flege, J. E. (2001). "Factors affecting degree of foreign accent in an L2: a review". Journal of Phonetics, 29, 191-215.

53. Sarantakos, S. (1997). Social research (2nd ed.). New York: Palgrave Publishers Ltd.

54. Schwarz, N., Bohner, G. (2001). The construction of attitudes. In A. Tesser \& N. Schwarz (Eds.) (2001), Intrapersonal Processes 
(Blackwell and book of Social Psychology), Oxford, UK: Blackwell, pp. $436-457$

55. Suter, R. W. (1976). Predictors of pronunciation accuracy in second language learning. Language learning, 26, 233-253.

56. Swan, M. (1982). "A critical look at communicative approach" (1). ELT Journal 39/1:12.

57. The Draft French Syllabus. 2014. for Diploma in Basic Education Programmes for Colleges of Education in Ghana. UCC: Institute of Education.

58. Yiboe, K. T. (2001). Problème de transfert négatif de la langueError! Bookmark not defined. première dans l'apprentissage de français en tant que langue étrangère: Le cas des apprenants au niveau Senior Secondary dans le district de Ho, Unpublished Masters Dissertation. Cape Coast, University of Cape Coast.

59. Yiboe, K. T. (2007). Analyse des principes méthodologiques dans l'Arc-en-ciel, Méthode de FLE au Ghana, Unpublished Masters Dissertation. Strasbourg, Université Marc Bloch.

60. Yiboe, K. T. (2010). Enseignement/ apprentissage du français au Ghana: Ecarts entre la culture d'enseignement et la culture d'apprentissage. Unpublished $\mathrm{PhD}$ dissertation, University of Strasbourg.

\section{Questionnaire}

This questionnaire has been designed to collect information about your perception of learning pronunciation in the target language, French. Please, first, give your background information, then read the statements and circle the number which appeals to you most. There is no right or wrong answer for this questionnaire. Feel free to do this exercise because your confidentiality is assured. Thank you.

\section{(a). Your background}

1. Name

of

College....

2.

Current

level...

3. Sex: Male [ ]; Female [ ]
4. Age:
a. 16 to 20 years
b. 21 to 24 years
c. 25 to 29 years

d. 30 to 34

years

e. 35 to 39 years

\section{(b). The Pronunciation Attitude Inventory (PAI)}

Please answer all the items using the following response categories 


\section{$5=$ Always or almost always true of me \\ $4=$ Usually true of me \\ $3=$ Somewhat true of me \\ $2=$ Usually not true of me \\ $1=$ Never or almost never true of me}

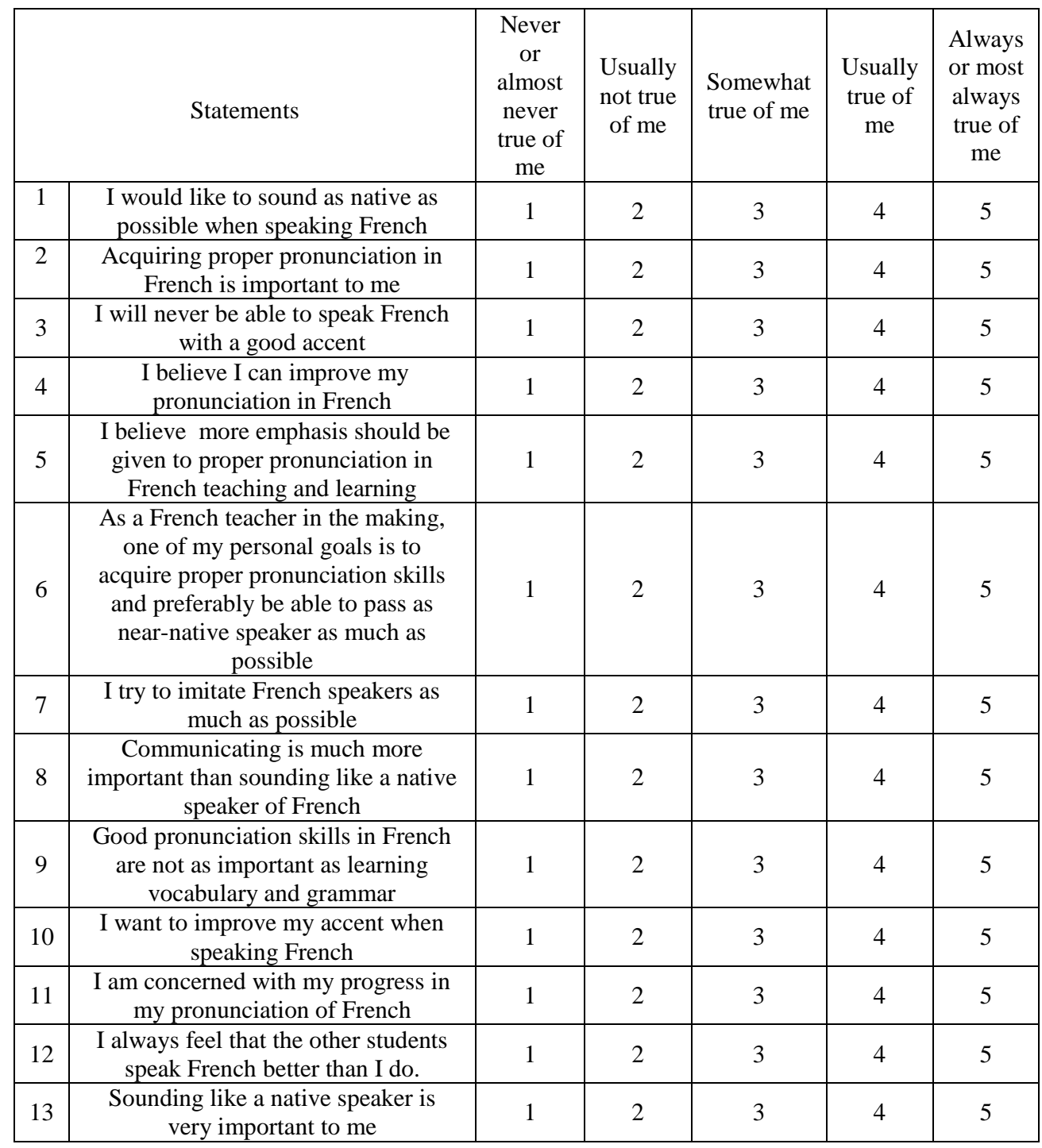

(Adapted from Elliott, 1995) 